\title{
Watering Country: Aboriginal partnerships with environmental water managers of the Murray-Darling Basin, Australia
}

Sue Jackson ${ }^{1}$ and Deb Nias ${ }^{2}$

\begin{abstract}
A complex environmental water governance system has developed in Australia over the past decade, with institutional arrangements that allow government and non-government organisations to acquire and manage substantial volumes of water for the benefit of the environment. Management of environmental water in partnership with other parties presents Aboriginal people with an opportunity to access water and restore environments, as well as reaffirm and rebuild socio-ecological relationships and water-dependent livelihoods. This paper describes the emergence of collaborative partnerships between environmental water managers and Aboriginal community organisations in the Murray-Darling Basin to water country. Through case study profiles, the paper shows how Aboriginal organisations and water managers are working together to improve the quality of wetlands, as perceived by traditional owners and others, and to share more equitably in the benefits from the acquisition and management of environmental water. The constraints and barriers are discussed, alongside the conditions that have laid the foundations for this emerging form of co-management of water.
\end{abstract}

\footnotetext{
${ }^{1}$ Australian Rivers Institute, Griffith University, sue.jackson@griffith.edu.au

2 Murray Darling Wetlands Working Group
} 


\section{Introduction}

Over the past 20 years, Australian society has endeavoured to address the over-allocation of water, declining inflows and acute environmental degradation in its agricultural regions. Recovering and setting aside water for the environment is a key feature of the reforms instituted across Australian jurisdictions, but most intensively in the Murray-Darling Basin (MDB), where protection and formal legal status for environmental water accords it equivalence with consumptive rights (Foerster 2011). Governments have endorsed voluntary buy-backs of water and trading as reallocation mechanisms, giving rise to a relatively complex environmental water governance system supporting the acquisition and management of substantial volumes of water, especially by the Commonwealth government.

The existence of a large environmental water reserve could present the numerous Aboriginal nations of the MDB with opportunities to contribute to the restoration of aquatic environments within their traditional estates, as well as reaffirm and rebuild socio-ecological relationships and water-dependent livelihoods. For more than a decade, Indigenous organisations have been explicitly pursuing such goals from within the Australian water sector. Whether such opportunities will be realised however, depends on a number of factors that include secure title to land, access to water entitlements, infrastructure, finance and other capacities to facilitate watering and restoration activities. There are undoubtedly significant barriers (Tan and Jackson 2013; Jackson and Langton 2012; Weir 2009; McAvoy 2008). For instance, Aboriginal people currently own less than 1\% of the Basin's land (Arthur 2012).

There are additional legal constraints that could affect the extent to which Indigenous people fulfil a strong or active role in environmental water management. Although the Murray-Darling 
Published in Australasian Journal of Environment Special Issue on Indigenous Water Management, Sept 2019, Vol 26, No 3: 287-303

Basin Plan (2012) contains an obligation to consult with Aboriginal peoples, consideration of Aboriginal interests is one of many Plan objectives that sits alongside requirements to implement international agreements and meet the water requirements of 'ecological assets'. The new Commonwealth Environmental Water Holder (CEWH) has the role of holding and managing water, but the purposes to which that person can direct water are tightly prescribed by the Water Act (2007), reflecting the prioritisation of ecological over socio-ecological objectives (Jackson 2017). Under current arrangements any identified Aboriginal priorities need to align with or enhance environmental outcomes, linked to asset sites identified in the Basin planning process (Capon and Capon 2017). A technical preoccupation with a scientifically determined river flow regime risks neglecting critical relational water values characteristic of Indigenous water cultures (Finn and Jackson 2011; Weir 2009; Strang 2005; McAvoy 2008).

The many Indigenous water declarations issued over the past decade confirm that the volume and timing of river flows, and their quality, are of great concern to many Indigenous people, as is the ability to manage and control water (Taylor et al. 2017). The literature also contains numerous reports from Indigenous groups concerned that environmental water has not been directed to features they consider to be of the greatest significance or value, or at the appropriate time (Jackson et al. 2015; Finn and Jackson 2011; Weir 2009; 2011). These concerns exist alongside wider aspirations to maintain and reaffirm relationships with country (including exercising jurisdiction over customary land and waterscapes), fulfill intergenerational responsibilities, and apply and teach traditional knowledge and skills to younger generations, as well as pursue livelihoods that may rely on access to water and/or bountiful aquatic ecosystems use (e.g. fishing, hunting and gathering, tourism). 
Published in Australasian Journal of Environment Special Issue on Indigenous Water Management, Sept 2019, Vol 26, No 3: 287-303

Yet studies have shown that environmental water policy and practices are not sufficiently inclusive of Indigenous knowledge, values, rights and interests (Finn and Jackson 2011; Taylor et al. 2017; Maclean and The Bana Yarralji Bubu Inc 2015; Jackson and Barber 2013; Jackson et al. 2012; Weir 2009; Hemming et al. 2017). In the MDB and other Australian regions, flow assessments undertaken by state agencies have made few attempts to understand the pattern and significance of Indigenous resource use or wider relationships with water (Jackson et al. 2015; Finn and Jackson 2011). Recent advocacy from Aboriginal representative organisations, and the actions of some within the water sector, is however effecting change. Such change is reflected in the growing interest in and support for the notion of 'cultural flows' and in policy and procedural changes in water agencies (MLDRIN et al. 2018), including the Murray Darling Basin Authority (MDBA) and the office of the CEWH.

In this article, we focus on the ways that environmental water managers of the MDB are developing inclusive processes and responding to Aboriginal water management objectives in their water purchases and management programs. We apply the National Water Commission's interpretation of environmental water to define environmental water managers as those who manage 'the water regime provided to achieve environmental objectives', including maintaining ecosystem function, biodiversity, water quality and river health targets (O’Donnell 2013a, n.p). Recent experimentation at a number of small localities within most States in the Basin shows that places and features of significance to traditional owner groups are receiving environmental water under collaborative partnerships between government and nongovernment water holders and managers. We have chosen to examine the interactions between environmental water managers and Aboriginal organisations in the MDB and no other geographic regions, such as north Australia where there are also significant water management issues (see for example, Jackson and Barber 2013; Taylor et al. 2017), because environmental 
Published in Australasian Journal of Environment Special Issue on Indigenous Water Management, Sept 2019, Vol 26, No 3: 287-303

water is most actively and intensely managed in the MDB. The MDB's well-developed institutional arrangements are quite distinct, with both public and private organisations holding entitlements for environmental purposes.

The instances we profile represent constructive attempts to engage formally Aboriginal people, to define the flows of water for ecosystem features that are commonly valued, and apply water under conditions that enhance Aboriginal custodianship. Through these activities, environmental water managers are advancing national water policy, which explicitly seeks to improve Indigenous access to water (Jackson and Morrison 2007; Taylor et al. 2017). Aboriginal employment is a key feature of these arrangements and all parties value crosscultural knowledge exchange. We argue that these cases are significant beyond the water management sector because they represent the development of a new form of co-management, or sharing of power and responsibility between government and local communities (Berkes 2009), within Australia's system of natural resource management (Zurba et al. 2012; Hughey et al. 2017; Tan and Jackson 2013; Sarker, Baldwin and Ross 2009).

The article structure is as follows. In the next section, we introduce the environmental water management system and describe the emergence of environmental water holders and managers. In the sub-sections to follow, we detail the origins, role and activities of three of the major environmental water managers/holders: the CEWH, the Murray Darling Wetlands Working Group and Nature Foundation SA's Water for Nature. We then profile three cases of 'watering country' under multi-party collaborative arrangements in NSW and South Australia involving these major environmental water managers. A discussion and conclusion follow the case studies. 
Published in Australasian Journal of Environment Special Issue on Indigenous Water Management, Sept 2019, Vol 26, No 3: 287-303

\section{The growth of environmental water managers}

Legal recognition of the environment as a legitimate water 'user' and the need for scientific determination of environmental flows has been closely followed by questions about who should provide water for the environment, and how (Garrick and O'Donnell 2015). A proliferation of new government and non-government environmental organisations has assumed responsibility for acquiring and managing environmental water in the MDB across multiple scales (O’Donnell 2013a). Growth in this sector has occurred because of the challenge of managing increasing volumes of environmental water in the context of active water markets (O'Donnell 2013a). This transformation of the water governance landscape also reflects the historical shift in the purpose of water management from a narrow emphasis on production outcomes typical of previous eras to a broader sustainability goal. Managing wetlands and rivers for environmental outcomes thus introduces imperatives that require fundamental changes to institutions (Foerster 2012; Garrick and O'Donnell 2015; Owens 2016), demanding models that are collaborative, adaptive and responsive to scale.

The complexity of natural resource management in the MDB - its laws, policies and programs - and the materiality of water also demands these qualities from environmental water management institutions. Hydrological connectedness of environmental features and ecosystems warrants consideration of scale and temporal dimensions, as well as the inclusion of multiple stakeholders (Roberts et al. 2011). Environmental features that are dependent on water occur across a diversity of tenures governed by various institutional forms with actors often working across jurisdictions and in partnership: private, public, or jointly managed. In the past five years, there have been over 750 environmental watering events (Productivity Commission 2018). 
Published in Australasian Journal of Environment Special Issue on Indigenous Water Management, Sept 2019, Vol 26, No 3: 287-303

The mix of institutional arrangements has created a layered federal system of environmental water governance (Foerster 2012). A \$9 billion investment from the Federal Government has substantially increased Commonwealth holdings managed by the CEWH and the MDBA, and it will continue to do so. State holdings are also significant and there are non-government organisations that hold water, such as environmental water trusts. Water trusts either deliver and manage water on behalf of government, or receive donations of water or money to channel it to government and community projects.

In such a system, coordination between the layers is essential and efficacy will hinge on overcoming gaps in scientific knowledge of ecological responses to watering, fragmented holding of environmental water entitlements, as well as the sheer complexity of rules about water management that differ across jurisdictions and sometimes regions (O'Keefe and Crase 2015). It is here that provision of information and local community engagement have a critical role to play, no matter the combination of state agencies, non-government organisations and individuals.

In the following sub-sections, we describe the role of the largest government environmental water holder, the $\mathrm{CEWH}$, and the two largest non-government managers, the Murray Darling Wetlands Working Group (MDWWG) and the Nature Foundation SA (NFSA), as well as their respective Aboriginal engagement activities.

\section{Commonwealth Environmental Water Holder (CEWH)}

The single largest holder of water in the MDB is the CEWH, which is a statutory entity. Its tasks include deciding where to apply environmental water, delivery of this water and monitoring its effects. It typically targets wetlands and floodplains on public lands, within the 
Published in Australasian Journal of Environment Special Issue on Indigenous Water Management, Sept 2019, Vol 26, No 3: 287-303

bounds of the Water Act 2007, which restricts environmental watering in instances where it might have third-party impacts i.e. flooding private land (Robinson et al. 2014). Water held by the CEWH is managed in accordance with the MDBA's Environmental Watering Plan and with the Basin Plan (MDBA, 2010a). As noted by O'Keefe and Crase (2015), the Basin Plan might emphasise a hierarchically coordinated approach but the associated documents explicitly recognise the importance of harnessing local knowledge and participation. The CEWH emphasises approaches that work with landholders, catchment management authorities, natural resource management boards, local groups, and state governments (DSEWPAC 2013). The CEWH has employed six local engagement officers, one of whom is Indigenous and has experience in the water and NRM sectors. It has also invited local water trusts to manage some portions of the environmental water it holds (O'Keefe and Crase 2015).

\section{Aboriginal partnerships}

The CEWH has made a determined effort to engage with Indigenous communities and has collaborated with a number of Aboriginal organisations to provide water to places of importance to traditional owners. It has also formalised its relationship with two Aboriginal organisations via agreements. In 2016 the CEWH and the Ngarrindjeri Regional Authority, based at the mouth of the Murray in South Australia, signed an environmental water delivery partnership agreement which

... establishes a framework for coordinating environmental watering undertaken by the NRA and CEWH, including an agreed process for planning and managing the transfer, delivery and monitoring of Commonwealth environmental water in South Australia's wetlands, consistent with each party's obligations under the Basin Plan. 
Published in Australasian Journal of Environment Special Issue on Indigenous Water Management, Sept 2019, Vol 26, No 3: 287-303

The Ngarrindjeri Regional Authority approached the CEWH in order to ensure that it would follow Ngarrindjeri cultural protocols in the care of wetlands and waterbodies within Ngarrindjeri estates. The agreement establishes a process for the Ngarrindjeri Regional Authority to submit watering proposals to the $\mathrm{CEWH}$, commits the parties to develop a process for their involvement in the management of Commonwealth environmental water, and establishes an agreed communications protocol (Hemming et al. 2017).

The second organisation operating under an agreement with the CEWH is the Nari Nari Tribal Council. The Tribal Council manages a 7000 ha property, 'Toogimbie' with a frontage to the Murrumbidgee River at Hay, NSW (see Figure 1). Toogimbie is an Indigenous Protected Area (IPA) managed with the goal of restoring natural vegetation communities. A developed area is leased for irrigated cropping using a general security water allocation. The Nari Nari intend to revive a range of cultural practices on the area. The CEWH has now provided $1500 \mathrm{ML}$ in 2016-2017 and 1000ML in 2017-2018 to the Nari Nari to water a floodplain (Patricia Murray pers comm). According to Rene Woods, Vice Chair of the Tribal Council, the Nari Nari sees the agreement as beneficial because it acknowledges the Council's aspirations for a high degree of control over the watering (pers comm).

\section{The Murray Darling Wetlands Working Group}

The forerunner to the Murray Darling Wetlands Working Group (MDWWG) was the NSW Murray Wetlands Working Group (MWWG), which formed as an independent communitybased rehabilitation group in 1992. The Group initially consisted of a range of people, including many technical experts from various government departments, skilled and knowledgeable 
Published in Australasian Journal of Environment Special Issue on Indigenous Water Management, Sept 2019, Vol 26, No 3: 287-303

locals from industry, business and conservation groups (Nias et al. 2003). Having developed a basic framework to guide decision making for environmental water, based on ecological needs of wetlands and river flow conditions, it assumes responsibility for the entire cycle of management - from identification and assessment, to delivery, monitoring and reporting.

From 2007 to 2015, the MDWWG delivered just over 74,000 ML of environmental water to 215 wetlands, conservatively estimated as covering more than 67,000 hectares. As well as the 150+ landowners, the Group collaborated with irrigation companies, government agencies, catchment management authorities, local councils; community groups including traditional owners, and research organisations.

Over its 25-year history, the Group has sought to establish itself as an effective partner for both private landholders and government organisations, and to build and maintain the legitimacy of environmental flows on private land. More recently it has sought to attract funds from new sources and to develop a long-term plan for the future, one in which owning water might secure a path to self-sufficiency. When introduced to the idea of social impact investment by The Nature Conservancy (U.S.), the MDWWG went into partnership with The Nature Conservancy Australia (TNC) and developed a new funding model in the form of the Murray Darling Basin Balanced Water Fund. Managed by Kilter Rural, the Fund provides water donations to the Environmental Water Trust, which is owned by TNC and the MDWWG. The fund was launched in 2015 to acquire water entitlements for wetland rehabilitation and to trade water back into agriculture. Within three years, the fund had raised $\$ 25$ million to buy just over eight GL of water in the southern Murray-Darling Basin.

The Environmental Water Trust is the first private trust in Australia dedicated to improving social, ecological and cultural outcomes for wetlands and rivers. The aim is for individuals and 
Published in Australasian Journal of Environment Special Issue on Indigenous Water Management, Sept 2019, Vol 26, No 3: 287-303

organisations to make donations or gifts of money, water licences or property to the trust, which has deductible-gift-recipient status. The donations can also be used to complement and integrate with state and federal government environmental watering programs. The priorities are wetlands of high conservation value that are located on private land and are not targeted by existing state or federal government watering plans. The water can also be used to 'piggy-back' on or complement water provided by governments to extend their environmental watering of threatened floodplain systems.

\section{Aboriginal partnerships}

For many years, the MDWWG was aware of the interests of Aboriginal people in water management, but it recognized the issue as one that needed more thorough attention in 2011, when it started working with the Nari Nari Tribal Council. As mentioned above, the Nari Nari were interested in monitoring techniques and the Working Group assisted them in developing a plan to record and monitor the effects of applying water to the Murrumbidgee floodplain. Since 2013, the MDWWG has extended its network of collaborators to work more closely with traditional owner groups in the southern MDB. This has resulted in formal partnerships that have generated environmental watering events at two sites (to be discussed below).

The Working Group identified Aboriginal communities as potential beneficiaries of their approach to water acquisition and management. The Trust has a Scientific and Cultural Advisory Committee through which two Aboriginal representatives provide advice on the MDWWG's Annual Environmental Watering Plan. The Aboriginal members also advise on protocols for collaborating with Aboriginal groups. The MDWWG also maintains a good working relationship with the representative body MLDRIN (Murray Lower Darling Rivers Indigenous Nations). 


\section{Nature Foundation South Australia and the Water For Nature Program}

Founded in 1981, the Nature Foundation SA's purpose is to 'advance nature conservation by raising funds, creating community partnerships and implementing sound science' (Nature Foundation SA no date). During the Millennium drought, Nature Foundation established a Water For Nature (WFN) programme, adding environmental watering to its repertoire of conservation strategies (Robinson et al. 2014). A committee of volunteers who are specialists in their respective fields, including water policy, irrigation, business, wetland ecology and natural resource management, guides the program. Initially the organisation purchased its own water allocation and then, in 2012, it entered into an agreement with the CEWH.

Since 2012, the NFSA, with the help of 200 volunteers, has delivered 11,684 ML of environmental water to more than 80 locations in the riverland and Murraylands. The program has recently developed a Five Year Environmental Watering Strategy to ensure its watering activities follow a sound scientific process and can adapt to a dynamic river environment. Most of these sites are privately owned and the watering is targeted at assisting the survival of river red gum and black box seedlings that naturally germinated in the 2010-12 floods. At other sites, the target is to provide water for waterbirds, frogs and other wildlife. The NSFA is now party to the state's annual environmental watering planning (Jensen 2016).

The cost of delivering water is noted as a challenge in the organisation's annual reports, one that has been overcome to some extent through philanthropic grants (see Nature Foundation 2014)

Aboriginal partnerships 
Published in Australasian Journal of Environment Special Issue on Indigenous Water Management, Sept 2019, Vol 26, No 3: 287-303

Nature Foundation SA has a number of projects that involve Aboriginal partners, including conservation planning on its nature reserves, working with Aboriginal rangers on rock-hole restoration and cultural heritage mapping, and a more recently instituted youth program (see Nature Foundation SA 2014). In the early years of the WFN program, the geographical focus was on the northern portion of the River Murray, where the organisation did not at that time engage directly with Indigenous groups. Once better established, the WFN program sought out relationships with Indigenous organisations in the southern Murray where the MDB NRM Board assisted the WFN team to identify potential watering projects. The program now explicitly includes sites of importance to Aboriginal people within its ambit, including properties under Aboriginal management (Jensen 2016). At these sites, cultural values are also the target for environmental watering, alongside red gum \& lignum wetland restoration.

In the following section, we describe three cases in which thesegovernment and nongovernment organisations are partnering with Aboriginal communities to achieve environmental and social (including cultural) outcomes from water management.

\section{Watering country: Case examples}

Fletcher's Creek, Dareton, NSW

Fletcher's Creek lies within the traditional estates of the Barkandji people of western NSW, close to Wentworth and Dareton (see Figure 1). The Barkindji Maraura Elders Environment Team (BMEET) receives Working on Country funding and for some years has been undertaking cultural and natural resource management activities on public land. It provides training and employment in an area with high rates of unemployment and social disadvantage (Barkandji Maraura Elders Environment Team no date). 
Insert Figure 1 somewhere around here

Fletchers Lake and the associated wetlands have provided a rich environment for Aboriginal people for thousands of years. Since 2011, BMEET has run a natural and cultural heritage works program on the Fletcher's Lake Reserve, a 3600 ha reserve managed as a drainage area by the Department of Primary Industry. The NSW Office of Water has recently granted the Barkindji a licence to occupy the reserved land. Current activities include fencing, pest plant and animal control, vegetation surveys, heritage protection measures, knowledge exchanges with scientists and well-being camps. BMEET has developed a cultural heritage management plan for the Reserve.

According to the former coordinator of $\mathrm{BMEET}^{3}$, this natural system would fill up when there was a small flood into Fletchers' Lake enabling boating, fishing and other uses. As irrigation technologies improved the water dried up. Construction of a culvert and bridge further affected the hydrology. In 2011, the Barkindji Mauru elders identified Fletchers Creek as a priority site for environmental water and soon after entered into a partnership with the MDWWG to deliver and monitor environmental watering. The relationship was initiated by the Working Group's former Chair, Howard Jones, who lives at Dareton and was interested in the potential to improve the condition of wetlands of value to Barkindji.

\footnotetext{
${ }^{3}$ The coordinator passed away soon after this interview was conducted in November 2016. Because it was not possible to check whether he wanted to be referred to by name in this article, as was done with other people interviewed, we have removed his name from the text.
} 
Published in Australasian Journal of Environment Special Issue on Indigenous Water Management, Sept 2019, Vol 26, No 3: 287-303

By agreement with the NSW Office of Environment and Heritage, 360 ML of Adaptive Environmental Water was delivered to Fletchers Creek to inundate approximately five kms in December 2013. In May 2016, a further 200 ML was delivered at a time when there was less evaporation loss. The MDWWG refers to this as 'the first cultural water application to be submitted in the region' (Wells 2018). The MDWWG provided the pump and operated it during these events, while Western Murray Irrigation assisted by approving the use of the shed, sump and pipework through the road crossing.

BMEET has been responsible for monitoring the environmental outcomes from recent watering in collaboration with the Murray Darling Freshwater Research Centre. This work, which included monitoring of tree condition, understorey vegetation, Lignum condition and photo point time series, became an extension of BMEET's NRM training.

The former coordinator described the benefits:

To bring back native food plants, yabbies'... it's been pretty barren here. It has brought back a lot of health, box trees. We went down there this morning, there is still water there May this year. People felt good that there was water they could see and go and hang out. To see water on their country. It's too dry here normally. It brought people back to country to camp and spend time there. It also seemed to bring more emus, nesting, that was noticeable. It meant that people could collect more emu eggs (interview November 2016). 
Published in Australasian Journal of Environment Special Issue on Indigenous Water Management, Sept 2019, Vol 26, No 3: 287-303

Because Fletcher's Creek is only 10 minutes out of town, the coordinator saw that the Barkindji were getting great value from the watering, and the rangers employed to undertake the associated monitoring program had much to gain and contribute:

They have knowledge but they don't know it because of dislocation. We say to them 'just feel it... what do you think is going on'. They respond well to that and are very observant. They look at the tree-tops and make estimates of tree health. They are far better at looking at country than scientists from the city and we demonstrated that. They were better able to see different plants than some of the scientists. The TOs could discriminate species. They are living it. Everything is living so it has characteristics. People are observant because they are trying to get food. Today we were looking for an emu nest. We haven't found it yet. There is curiosity born out of deep observation" (interview November 2016).

Carrs, Capitts and Bunberoo (CCB) Creeks system, NSW

In 2016, the MDWWG and CEWH initiated a multi-stakeholder partnership to deliver water to the Carrs, Capitts and Bunberoo (CCB) Creeks system and Backwater Lagoon on the floodplain of the Moorna State forest, in south-western NSW (see Figure 1). The land, which is near Wentworth, is part of a Crown reserve managed by the NSW National Parks. It is in the process of being returned to Barkindji traditional owners, represented by the Ta-Ru Lands Board of Management. Ultimately, Barkindji will manage it as an Indigenous Protected Area.

The aim was to rejuvenate the threatened River Red Gum and Black Box ecological communities and the wetlands associated with these creeks that had not received environmental water since 2006. Additionally, the watering program was to provide opportunities for 
Published in Australasian Journal of Environment Special Issue on Indigenous Water Management, Sept 2019, Vol 26, No 3: 287-303

Barkindji to be involved in monitoring to assist future management. In this instance, five sites were provided with $950 \mathrm{ML}$ of environmental water managed by the $\mathrm{CEWH}$, and an additional 350 ML to Backwater Lagoon (Owens 2016). The cost of water delivery like this is substantial, in this case amounting to at least $\$ 150,000$ for water charges, use of pumps, water access permitting and approvals, monitoring and reporting.

The CEWH provided the water from the Murray River. Richard Mintern of the CEWH explains that the site was chosen because 'there were parallel lines of interest' in its restoration. He also highlights the role of key individuals who were active in local NRM networks and those who, like himself, had long-standing relationship with traditional owners:

Howard Jones who was the Chair of the MDWWG had an interest in that landscape, remembering it as a good fishing spot. My interest stemmed from looking at satellite imagery and seeing a lagoon near Lock 8 on the station next to the Crown Land managed by National Parks. I then recognised that the entire landscape was suitable for an intervention and spoke to Kenny Clark at National Parks and the Executive Officer responsible for the transition to an IPA. We came to a collective agreement. It was a partnership of lots of people. There were complex tenure arrangements that required neighbour approval for site access. Lots of coordination was needed (interview May 2018).

At the outset of this project, organisers anticipated a role for the Ta-Ru Lands Board of Management in monitoring environmental outcomes, including plant species that have cultural significance. The CEWH obtained funds to establish an ecological and cultural monitoring plan and to engage local consultants, Sunraysia Environmental, to train Barkindji participants in 
Published in Australasian Journal of Environment Special Issue on Indigenous Water Management, Sept 2019, Vol 26, No 3: 287-303

environmental field monitoring techniques. Objectives for the watering were developed at a workshop where the Barkindji identified the preservation of scar trees, restoring traditional medicine plants etc. The results will inform future watering at the sites.

Lower Murray Wetlands, SA

In 2012, a partnership struck with the CEWH provided the Nature Foundation SA (NFSA) with an opportunity to manage $10 \mathrm{GL}$ of environmental water, annually for five years ${ }^{4}$ (O'Keefe and Crase 2015). In total, the volume is considered a relatively small portion of the CEWH's water reserve (O'Keefe and Crase 2015) but it is the largest of the cases discussed here.

The NFSA identifies and proposes local uses, establishing that these watering events are consistent with the functions of the CEWH, which are then assessed on a case-by-case basis according to the Framework for Determining Commonwealth Environmental Water Use (O'Keefe and Crase 2015). The partnership includes funding for the physical delivery of environmental water, but has been subsidised significantly by philanthropic funding since 2016. The environmental water allocation is transferred to a Nature Foundation SA licence via the SA Minister for the River Murray, any unused allocation being transferred back to the $\mathrm{CEWH}$ at the end of the watering season. Nature Foundation SA receives a fixed rate per mega litre from the CEWH for environmental water delivery services.

Two Aboriginal organisations that fall under the umbrella of the Ngarrindjeri Regional Authority (NRA) have been involved in the WFN Program. In both cases, relationships

\footnotetext{
${ }^{4}$ The agreement has since been extended until 30 June 2019.
} 
Published in Australasian Journal of Environment Special Issue on Indigenous Water Management, Sept 2019, Vol 26, No 3: 287-303

between Aboriginal leaders, wetland specialists and in particular the CEO of the NFSA were instrumental in establishing these arrangements (interview Matt Turner, June 2018). Staff of the WFN program identified the sites to be watered, with input from the local NRM Board, and in consultation with Aboriginal community leaders. Ian Atkinson, former CEO of the NFSA, recalls that LIDAR data revealed that the Raukkan region could benefit from the application of water and, from there, a project developed (interview, December 2018).

The Raukkan Community Council, based at Lake Alexandrina, in collaboration with Ngopamuldi Aboriginal Corporation, was contracted to manage the Nature Foundation SA pumps and oversee the large environmental watering events on Aboriginal land at South Teringie station where 215.468 ML was delivered over 2 years (2014-15 and 2015-16) (see Figure 1). Payments from WFN to Raukken were based on the volume of CEWH water delivered (interview, Matt Turner, June 2018). A Working on Country team undertook monitoring and reporting of environmental responses. This organisation had developed capacity through their involvement in a long-standing MDB e-flows project at the Coorong Lower Lakes and it was, according to Ian Atkinson, very adept at managing the physical works and engaging community members.

The joint project encouraged the Ngarrindjeri Regional Authority to establish their own agreement with the CEWH in 2016. Responsibility for watering this area will transition to the NRA under a renewed agreement being negotiated with the CEWH (Derek Walker, 8 August 2018). The Nature Foundation assisted with the NRA plans by handing over relevant government approvals and information. Derek Walker from the Ngopamuldi Corporation said that 'it makes an incredible difference getting water on country. These areas wouldn't get water 
otherwise. The partnership with the Nature Foundation was solid and having a direct relationship with the CEWH was gold' (interview 8 August 2017).

The second smaller project was undertaken at an Aboriginal property on the Murray River managed by the Nganguraku, as part of the Ngarrindjeri Nation, through the Mannum Aboriginal Community Association Inc. and Sugar Shack Aboriginal Corporation (Hemming et al. 2017). Sugar Shack wetland, which is part of the Swan Reach wetland complex, has been recognised as a place of significance to the Ngarrindjeri for many years (see Mooney et al. 2014), as it is part of the Ngurunderi Creation story of the Ngarrindjeri Nation (Hemming et al. 2017) (see Figure 1). The Sugar Shack wetland complex is also listed as a Key Environmental Asset in the Guide to the Basin Plan. A management plan for the property developed by the NRA states that:

The Sugar Shack Complex is part of the living body of Murrundi (River Murray) and was created by Creation Ancestors such as Ngurunderi, Pondi (Murray Cod) and Thukabi (Macquarie Tortoise) and cared for by generations of Ngarrindjeri. Ngarrindjeri people past, present and future are part of the living body of Murrundi. For this part of Murrundi to continue to give life to Ngarrindjeri people it must be healthy and cared for in a culturally respectful manner (NRA 2015, 1).

According to this plan, which identified features of significance to traditional owners and others, the Ngarrindjeri vision for the Sugar Shack complex is that it 'become a best-practice example of Indigenous wetland management, incorporating Indigenous knowledge, practices, objectives and visions... [and] that water allocation planning for the site (and other's within the area) becomes consistent with Ngarrindjeri aspirations and responsibilities' $(2015,14)$. 
The Mannum Association was contracted under similar terms to those of Raukken. In 201516, Mannum Aboriginal Community Association Inc. assisted NFSA and the Eastern Hills Murray Plains Catchment Group in the delivery of $58.58 \mathrm{ML}$ of environmental water to Greigers at Sugar Shack wetland. Assisted environmental watering did not go ahead in 2016 because of high water levels. Sugar Shack wetland may receive water from the WFN program in the next twelve months and the NRA intends to develop watering proposals for their country over the next few years (Hemming et al. 2017).

\section{Discussion and conclusion}

In the watering activities described in this article, it is clear that the major public and private environmental water management organisations are responding to the place-based attachments of Aboriginal groups who prioritise local connections and localised measures of significance (e.g. fishing grounds, wetlands of historical significance, sacred sites) and are seeking to regain control of their country.

Non-government environmental water managers appear to be regarded by government agencies as appropriate agents to deliver water because they bring a depth of local knowledge to the design of watering programs. In the cases above, this capacity now includes an ability to negotiate partnerships with Aboriginal peoples who until recently have not participated directly in environmental water management in the Basin, although as the SA case shows, they are likely to do so in the near future. For these reasons, government agencies are devolving responsibilities and funding and have encouraged the non-government partners to trial new decentralized modes of delivery and monitoring of locally significant wetlands (Robinson et al. 2014). 
Although small in number, the cases described in this article demonstrate that Aboriginal organisations and government and non-government water managers are working together to improve the quality of wetlands, as perceived by traditional owners, and to share more equitably in the benefits from the acquisition and management of environmental water. By pooling resources these groups are collectively overcoming the constraints that any one may face alone. The prerequisite resources include access licences in the possession of either government or non-government organisations, equipment such as pumps and fuel and funding for labour and licensing fees. These resources also include the skills and knowledge to negotiate administrative pathways, as well as to observe properly the rights and responsibilities to make decisions under Aboriginal law and elicit ecological knowledge of country. In another study of environmental water management in the MDB, Robinson et al. $(2014,10)$ observed that such 'transaction costs' can be significant. .

It is worth noting that secure title to land appears to be an influential if not threshold factor in these cases, as is of course secure access to water. All of the projects discussed above are located on lands where traditional ownership is recognized by state agencies, for example, they are under joint management arrangements or have been returned to Aboriginal people. It is possible that the very low proportion of land in the basin held by Aboriginal people under secure title could limit the future growth of the kind of partnership arrangements described here. Overcoming this constraint in the absence of conventional land restoration programs will require at the least that government, non-government and Aboriginal parties negotiate agreements to ensure Aboriginal jurisdiction is acknowledged and watering can be undertaken with legal certainty. 
The significant complexity of the water management sector as a driving force in these arrangements should not be underestimated. There are few organisations that have the capacity to deliver on the objectives of the case study projects described and to meet their administrative requirements (O'Keefe and Crase 2015; Roberts et al. 2011). The experience and knowledge that established environmental water managers bring to the task of watering country is therefore an obvious benefit to Aboriginal groups such as the Ngarrindjeri Regional Authority or the Nari Nari Tribal Council, which have demonstrated considerable initiative in seeking out comanagement partners, and plans to increase their capacity to operate in this rapidly developing field.

That environmental water managers are undertaking this kind of valuable bridging work is consistent with the literature that identifies as one of the strengths of co-management the capacity of different partners to draw on their networks and experience and bring to the process knowledge that is required at different scales (Berkes 2009). As this literature argues, bridging scientific and local knowledge production processes is not easy. More intensive research in these or other case contexts may give greater exposure to underlying difficulties and the strategies that collaborators are employing to address them. Based on our experience, we can anticipate that the sheer cost of water delivery could be an impediment to small Indigenous organisations managing water independently. In the cases explored here, collaborating partners had to meet the cost of infrastructure, planning and monitoring, as well as water charges and licencing fees. Where pumps and other infrastructure are required to deliver water to discrete sites, the costs pass to the holder or manager of water rights (O'Keefe and Crase 2015). To our knowledge, funding programs designed to assist Aboriginal land management organisations, 
such as the Commonwealth's Indigenous Protected Area program, do not cover the costs of water acquisition or delivery.

The question of the adequacy and sustainability of funding is likely to remain a vexed one for some time. Current arrangements do not provide Aboriginal land management groups, or indeed the non-government groups discussed here, with a secure source of funding to cover the running costs of a representative and responsive organisation. As the MDWWG and WFN have found, there is a need to move beyond a fee for service contractual arrangement, where little account is taken of the wider overheads, because this leaves non-government groups with little means to sustain core business. Moreover, without funds to invest in the whole cycle of adaptive management, from planning to implementation and particularly collaborative interpretation of results and development of adaptations, groups will be hampered in achieving their wider goal of effecting change that is more lasting. Long-term investment is critical for building relationships, for continuity in delivery and for expanding regional capacity.

Compensation for the Aboriginal labour deployed to the kinds of restoration and community development projects described above is also an issue yet to be consistently addressed by water managers and, in one case at least, finding an enabling mechanism to pay Aboriginal participants in various capacities was difficult. For example, the Ta Ru Lands Board was not incorporated and hence could not employ Barkindji traditional owners, whereas the MDWWG was able to employ individuals to monitor ecological responses on a casual basis (Mintern, pers comm). In the SA watering projects, Aboriginal organisations were paid on a fee for service basis to undertake the watering, reflecting a commitment from that organisation to pay all groups delivering such services, including Landcare groups. Whereas in the NSW cases involving the MDWWG and the CEWH, Aboriginal organisations were not paid to undertake 
Published in Australasian Journal of Environment Special Issue on Indigenous Water Management, Sept 2019, Vol 26, No 3: 287-303

watering activities, however, they did receive funds or assistance to directly monitor ecological responses and impacts. The legitimate expectations of Aboriginal communities for gainful employment on their country in pursuits that are often undertaken in the service of a wider public interest may contribute to increasing the cost of these endeavours. Such costs will need to be weighed against more fulsome evaluations of the benefits of equitable Aboriginal participation.

While it is apparent that long-standing personal relationships and leadership have been critical to the success of these partnerships, we can see in these cases attempts to formalise arrangements and potentially make the act of power sharing more equitable (Berkes 2009). This has taken the form of environmental water delivery partnership agreements signed between the Ngarrindjeri Regional Authority, the Nari Nari Tribal Council and the CEWH and an agreed role for Aboriginal advisors to the Environmental Water Trust established by the MDWWG and TNC Australia. In the case of the Ngarrindjeri, this agreement with the CEWH serves an explicitly political purpose for it represents an important step in regaining 'control over its jurisdiction by forming co-management partnerships with NRM policy makers in government' (Hemming et al. 2017, 13). There are hopes for more such local agreements between traditional owner groups and the CEWH, according to Rene Woods, who is also the Chairperson of MLDRIN. 'The CEWH has said that she wants to see it lead the movement towards incorporating cultural objectives and values in environmental water' (interview 5 July 2018).

Further research could more fully investigate the power dynamics at play in these comanagement arrangements, particularly the ways in which trust, which is regarded as an determinant of the success of co-management (Berkes 2009), was established and how any barriers to its maintenance were negotiated through agreements or other mechanisms (Jackson 
Published in Australasian Journal of Environment Special Issue on Indigenous Water Management, Sept 2019, Vol 26, No 3: 287-303

2018). Whether there were common stages or steps in the collaborative processes established and sustained in these instances is also of interest and worthy of more detailed analysis, particularly given recent emphasis in studies of co-management on the dynamics of continuous problem-solving (Zurba et al. 2012). As is the extent to which these arrangements enable effective decision-making by Aboriginal groups (cf. Hemming et al. 2017).

According to Berkes (2009; see also Zurba et al. 2012), long-term studies characterize comanagement as a process in which relationships among the parties are constantly changing. As bridging organisations like the ones profiled here continue to develop and expand linkages across the research, government, private and Indigenous sectors, we can expect to see the comanagement models described here evolve and for more opportunities arising for Indigenous peoples to benefit from water management.

The guidelines for cultural flow assessments recently released by the Murray Darling Rivers Indigenous Nations, the Northern Basin Aboriginal Nations and the North Australian Indigenous Land and Sea Management Alliance is a case in point (Murray Lower Darling Rivers Indigenous Nations et al. 2017). These guidelines can provide others not yet engaged with Aboriginal organisations with a set of resources that may increase the direct participation of Aboriginal people in environmental water management. To implement the vision of that project will require increased resources to help build the capacity of Aboriginal organisations to manage water. Training in all aspects of water management for Aboriginal people is a vision being developed by the consortium now responsible for management of the Nimmie Caira region in the Murrumbidgee, NSW. Consisting of the Nari Nari Tribal Council, The Nature Conservancy Australia, Murray Darling Wetlands Working Group and the University of NSW. 
Published in Australasian Journal of Environment Special Issue on Indigenous Water Management, Sept 2019, Vol 26, No 3: 287-303

Impetus for change may also come from mandatory requirements for water management agencies to engage with Indigenous peoples. Recently, the Federal Minister directed the MDBA to report annually on how environmental water holders have considered Indigenous values and uses and involved Indigenous peoples in plans for environmental watering (Productivity Commission 2018).

Aboriginal people have expressed a commitment to the twin goals of environmental and cultural restoration after many decades of dispossession and degradation. With this commitment traditional owner groups have grown more and more interested in the institutional models of acquisition and management of water entitlements that have developed in the MDB. This interest and preparedness shown by the emerging environmental water management sector to collaborate with Aboriginal water managers is a promising development for the Basin and beyond. Recent bipartisan commitments from the major federal parties to substantially increase funding for Aboriginal communities to invest in water entitlements for both economic and cultural purposes could see this form of co-management expand considerably across the region. Insights and lessons learnt from the cases examined here will assist any such efforts to upscale the watering of country.

\section{Acknowledgements}

This project was supported by the Australian Research Council's Future Fellowships Program funding scheme (project number FT130101145). We are grateful to the staff and executive members of the organisations involved in Aboriginal water management partnerships. We also 
Published in Australasian Journal of Environment Special Issue on Indigenous Water Management, Sept 2019, Vol 26, No 3: 287-303

thank the anonymous reviewers of the draft manuscript. All remaining errors are the responsibility of the authors.

\section{References}

Arthur, B. 2012. "The Murray-Darling Basin Regional and Basin Plans: Indigenous Water and Land Data." Canberra, Murray Darling Basin Authority.

Barkandji Maraura Elders Environment Team. No date. https://bmeet.weebly.com/about.html, viewed 7 July 2018.

Berkes, F. 2009. "Evolution of Co-management: Role of Knowledge Generation, Bridging Organizations and Social Learning.” Environmental Management 90: 1692-1702.

Capon, S and T. Capon. 2017. "An Impossible Prescription: Why Science Cannot Determine Environmental Water Requirements for a Healthy Murray-Darling Basin." Water Economics and Policy, 3: 1650037

Commonwealth of Australia, 2018. Commonwealth environmental water holdings [online].

Canberra, Commonwealth Environmental Water Office. Available from: http://www.environment.gov.au/water/cewo/about/water-holdings [Accessed 16 May 2018].

Finn, M and S. Jackson. 2011. "Protecting Indigenous Values in Water Management: A Challenge to Conventional Environmental Flow Assessments”. Ecosystems 14: 1232-1248. 
Published in Australasian Journal of Environment Special Issue on Indigenous Water Management, Sept 2019, Vol 26, No 3: 287-303

Foerster, A. 2012. "Emerging Environmental Governance in Australia". The Journal of Water Law 22: 58-72.

Garrick. D. and E. O’Donnell. 2015. "Exploring private roles in environmental watering in Australia and the U.S.” In Protecting the Environment Privately, edited by J. Bennett, 203-231. Singapore: World Scientific Publishing.

Hemming, S., D. Rigney, S. L. Muller, G. Rigney, and I. Campbell. 2017. “A New Direction for Water Management? Indigenous Nation Building as a Strategy for River Health". Ecology and Society 22(2):13. https://doi.org/10.5751/ES-08982-220213

Horne, A. and E. O’Donnell. 2014. “Decision Making Roles and Responsibility for Environmental Water in the Murray-Darling Basin". Australasian Journal of Water Resources 18: $118-132$.

Hughey, K., C. Jacobson, and E. F. Smith. 2017. “A Framework for Comparing Collaborative Management of Australian and New Zealand Water Resources”. Ecology and Society 22: 28.

Jackson, S. 2018. "Building Trust and Establishing Legitimacy Across Scientific, Water Management and Indigenous Cultures". Australasian Journal of Water Resources DOI:10.1080/13241583.2018.1505994 
Published in Australasian Journal of Environment Special Issue on Indigenous Water Management, Sept 2019, Vol 26, No 3: 287-303

Jackson, S. and M. Barber. 2013. "Indigenous Water Values and Resource Governance in Australia's Northern Territory: Current Progress and Ongoing Challenges for Social Justice in Water Planning". Planning Theory and Practice 14:435-454.

Jackson, S. and M. Langton. 2012. "Trends in the Recognition of Indigenous Water Needs in Australian Water Reform: The Limitations of 'Cultural' Entitlements in Achieving Water Equity". Journal of Water Law 22:109-123.

Jackson, S. and J. Morrison. 2007. "Indigenous Perspectives on Water Management, Reforms and Implementation." In Managing Water for Australia: The Social and Institutional Challenges, edited by K. Hussey and S. Dovers, 23-41. Melbourne: CSIRO.

Jackson, S., Pollino, C., Maclean, B., Moggridge, B. and R. Bark. 2015. "Meeting Indigenous Peoples' Objectives in Environmental Flow Assessments: Case Studies from an Australian Multi-Jurisdictional Water Sharing Initiative”. Journal of Hydrology 52: 141-151.

Jackson, S., Tan, P, Mooney, C., Hoverman, S. and I. White. 2012. "Principles and Guidelines for Good Practice in Indigenous Engagement in Water Planning". Journal of Hydrology 474: $57-65$.

Maclean, K. and The Bana Yarralji Bubu Inc. 2015. "Crossing Cultural Boundaries: Integrating Indigenous Water Knowledge into Water Governance Through Co-Research in the Queensland Wet Tropics, Australia”. Geoforum 59: 142-152. 
Published in Australasian Journal of Environment Special Issue on Indigenous Water Management, Sept 2019, Vol 26, No 3: 287-303

McAvoy, T. 2008. "The Human Right to Water and Aboriginal Water Rights in New South Wales." Human Rights Defender 17: 6-9.

Mooney, C. and P. Tan. 2014. "South Australia's River Murray: Social and Cultural Values in Water Planning”. Journal of Hydrology 474: 29-37.

Murray Lower Darling Rivers Indigenous Nations, Northern Basin Aboriginal Nations \& North Australian Indigenous Land and Sea Management Alliance. 2017. Cultural Flows: A Guide for Water Managers.

http://www.culturalflows.com.au/ culturalflowscom/images/documents/Water\%20Managers \%20Guide.pdf, viewed 7 November 2018.

Nature Foundation South Australia. 2014. Annual Report 2013-2014.

https://www.naturefoundation.org.au/publications/annual-reports/nf-annual-reportfy1314.pdf, viewed 8 October 2018.

Nature Foundation South Australia. no date. Nature Foundation SA on a Page. https://www.naturefoundation.org.au/getattachment/About-Us/Our-Vision/NFSA-Plan-on-aPage_v2.pdf, viewed 6 June 2018.

Nias, D., Alexander, P. and M. Herring. 2003. "Watering Private Property Wetlands in the Murray Valley, New South Wales.” Ecological Management \& Restoration 4: 5-12.

Ngarrindjeri Regional Authority. 2015. Sugar Shack Complex Management Plan. Ngarrindjeri Regional Authority, Murray Bridge, South Australia. 
Published in Australasian Journal of Environment Special Issue on Indigenous Water Management, Sept 2019, Vol 26, No 3: 287-303

O'Donnell, E. 2013a. "Australia's Environmental Water Holders: Who is Managing Our Environmental Water?" Australian Environment Review 28: 508-513.

O’Donnell, E. 2013b. “Common Legal and Policy Factors in the Emergence of Environmental Water Managers”. WIT Transactions on Ecology and the Environment 178: 321-333.

O’Keefe, S. and L. Crase. 2015. 'Non-Government provision of environmental water: A case from the Murray-Darling Basin." In Protecting the Environment Privately, edited by J. Bennett, Singapore: World Scientific Publishing.

Productivity Commission. 2018. Murray-Darling Basin Plan: Five Year Assessment. Draft Report, Canberra: Australian Government.

Roberts, A., Seymour, E. and D. Pannell. 2011. "The Role of Regional Organisations in Environment Water Management in the Murray-Darling Basin”. Australia. Economic Papers 30: $147-156$.

Robinson, C., Bark, R., Garrick, D and C. Pollino. 2014. "Sustaining Local Values Through River Basin Governance: Community-based Initiatives in Australia's Murray-Darling Basin.” Journal of Environmental Planning and Management 58: 2212-2227. 
Published in Australasian Journal of Environment Special Issue on Indigenous Water Management, Sept 2019, Vol 26, No 3: 287-303

Sarker, A., C. Baldwin and H. Ross. 2009. Managing Groundwater as a Common-Pool Resource: An Australian Case Study". Water Policy 11: 598-614.

Strang, V. 2005. "Water Works: Agency and Creativity in the Mitchell River Catchment." Australian Journal of Anthropology 16: 366-381.

Tan, P. and S. Jackson. 2013. "Impossible Dreaming - Does Australia's Water Law and Policy Fulfil Indigenous Aspirations?” Environment and Planning Law Journal 30: 132-149.

Taylor, K., B. Moggridge, and A. Poelina. 2017. “Australian Indigenous Water Policy and the Impacts of the Ever-changing Political Cycle." Australasian Journal of Water Resources 20: $132-147$.

Owens, K. 2015. "Irrigation Organisations and Environmental Water Transactions: A Comparative Analysis of Impediments and Opportunities in Relation to Environmental Water Recovery." The Australasian Journal of Natural Resources Law and Policy 18: 49-76.

Owens, K. 2016. "Reimagining Water Buybacks in Australia: Non-governmental Organisations, Complementary Initiatives and Private Capital." Environment and Planning Law Journal 33: 342-355. 
Published in Australasian Journal of Environment Special Issue on Indigenous Water Management, Sept 2019, Vol 26, No 3: 287-303

Wells, A. 2018. Against the Flow: How the Murray Darling Wetlands Working Group Pioneered the Restoration of Wetlands in the Murray and Darling Rivers. East Albury, NSW : Murray Darling Wetlands Working Group Ltd.

Weir, J. 2009. Murray River Country: An Ecological Dialogue with Traditional Owners. Canberra: Aboriginal Studies Press.

Zurba, M., H. Ross, A. Izurieta, P. Rist, E. Bock and F. Berkes. 2012. "Building CoManagement as a Process: Problem Solving Through Partnerships in Aboriginal Country, Australia". Environmental Management 49:1130-1142. 